Acta vet. scand. $1981,22,403-408$.

From the Department of Physiology, Veterinary College of Norway, Oslo.

\title{
THE IMMEDIATE EFFECT OF HCG UPON PLASMA TESTOSTERONE LEVELS IN THE BULL*
}

By

A. Sundby

SUNDBY, A.: The immediate effect of HCG upon plasma testosterone levels in the bull. Acta vet. scand. 1981, 22, 403-408. - No effect of HCG upon the plasma testosterone level in 16 bulls was seen the first 5 or 15 min after injection. In 8 bulls receiving 750 or 1500 i.u. HCG by intravenous injection a lag time of $30 \mathrm{~min}$ occurred before plasma testosterone response could be measured. The high plateau level of plasma testosterone concentration was reached approximately $1 \mathrm{~h}$ after injection.

Following intramuscular injection of 750 i.u. or 1500 i.u. HCG a lag time of $45-60 \mathrm{~min}$ was observed for the testicular response measured as elevated plasma testosterone level. The high plateau levels of plasma testosterone in these bulls were reached approximately $1 \frac{1}{2} \mathrm{~h}$ post injection.

bull; HCG; immediate effect; plasma testosterone.

This investigation was undertaken to study the immediate effect of HCG upon plasma testosterone levels in bulls. Frequent sampling, use of 2 doses, 2 routes of injection methods and an adequate number of bulls should make it possible to detect any immediate effect of $\mathrm{HCG}$ upon testosterone release, and to define the time lag between injection and testicular response in the form of increased plasma testosterone level.

\section{MATERIALS AND METHODS}

Sixteen Norwegian Red Breed bulls were studied. The bulls were 7 months old, weighing $200-220 \mathrm{~kg}$. The bulls were penned together indoors at the Bull Testing Station, Øyer, Norway.

* The investigation was financially supported by the Agricultural Research Council of Norway. 
Doses of 750 i.u. or 1500 i.u. HCG were given intravenously (i.v.) or intramuscularly (i.m.) to 4 bulls in each group. Blood samples were collected in a control period at 13,14,15, 16, 17, 18 o'clock on the day prior to injection and at 13,14 o'clock (in half of the bulls) on the day of injection. Further blood sampling was performed just before injection at 15 o'clock and then $5,15,30,45$, $60 \mathrm{~min}$ and $1 \frac{1}{2}, 2$ and $2 \frac{1}{2} \mathrm{~h}$ post injection. All blood samples were collected by jugular venipuncture into heparinized vacutainers (Vacutainer, Becton Dickinson, France) and centrifuged. The supernatant plasma was harvested and stored at $-20^{\circ} \mathrm{C}$ until analysed. Testosterone was assayed by the radioimmunoassay method of Sanwal et al. (1974) as modified by Sundby et al. (1975). HCG was analysed by a radioimmunassay at Aker Hospital, Norway by Dr. P. Torjesen (Sand \& Torjesen 1973).

\section{RESULTS}

Fig. 1 shows the plasma testosterone profiles in the control period and in the test period for the individual bulls, and the average plasma HCG profile in the 4 different groups. In the control period all the bulls had falling plasma testosterone level from 15-16 and remained at this low level from 16-17 o'clock.

\section{Intravenous $H C G$ injection}

No effect of HCG upon plasma testosterone was found 5 or 15 min after injection. Bulls with high plasma testosterone levels remained stable or dropped, while bulls having low plasma testosterone showed no change. Among 4 bulls receiving 750 i.u. HCG by i.v. injection (Fig. 1a) 2 remained on a high level following the injection, one of these showed a dip in plasma testosterone concentration after $45 \mathrm{~min}$. In the 2 other bulls, plasma testosterone started to rise 30 min post injection reaching a plateau level after $1 \mathrm{~h}$. The 4 bulls receiving 1500 i.u. HCG by i.v. injection (Fig. 1b) showed a marked rise in plasma testosterone concentration in the sample taken 30 min post injection, remained at this level or increased further until $1 \mathrm{~h}$ post injection when a plateau concentration was reached.

\section{Intramuscular HCG injection}

In the group receiving 750 i.u. HCG by i.m. injection all the bulls had falling plasma testosterone concentration in the sam- 


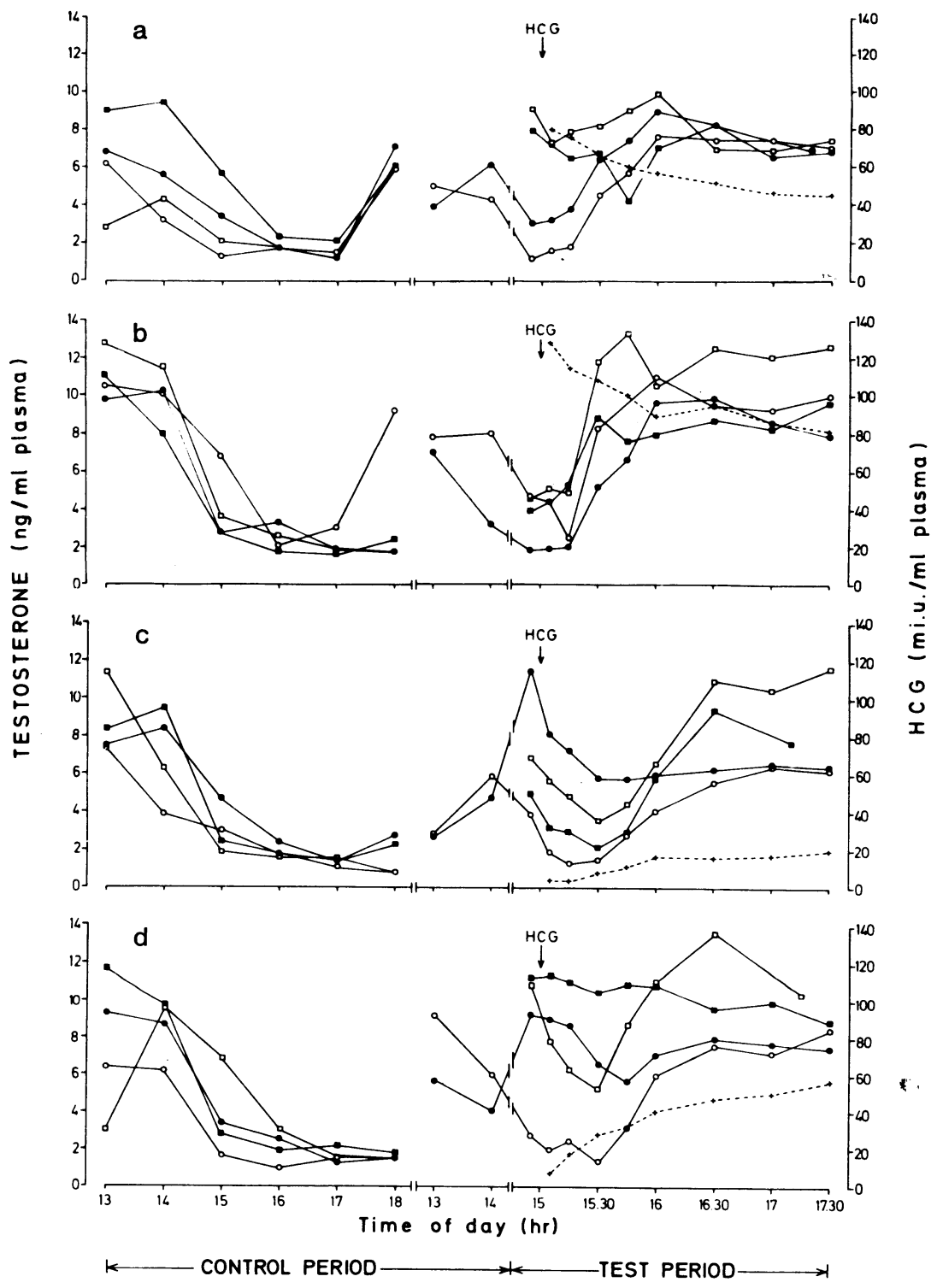

F i g u r e 1. Plasma testosterone levels in 16 bulls during a control period on the day before injection and following intravenous injection of 750 i.u. and 1500 i.u. HCG $(a, b)$ and intramuscular injection of 750 i.u. and 1500 i.u. HCG (c, d). Time of injection ( $\downarrow)$. Average HCG levels in each group of bulls +-..++ 
ples taken 5, 15, and 30 min post injection. Thereafter plasma testosterone concentration levelled out in 1 of the bulls while in the 3 others increasing concentrations were measured until a plateau was reached $1 \frac{1}{2} \mathrm{~h}$ post injection (Fig. 1c). In the group receiving 1500 i.u. HCG by i.m. injection the plasma testosterone concentration in 1 bull remained at a high level. The 3 other bulls showed first a fall, then a starting increase $45-60 \mathrm{~min}$ post injection and then a steady level from $1 \frac{1 / 2}{h}$ post injection (Fig. 1d).

\section{Plasma HCG values}

The average HCG level $5 \mathrm{~min}$ and $2^{1 / 2} \mathrm{~h}$ post i.v. injection of 750 i.u. HCG to 4 bulls were 80 i.u./l and 45 i.u./l, and for those receiving 1500 i.u. HCG 128 i.u./l and 82 i.u./l. The halflife for HCG was calculated to be $75 \mathrm{~min}$ the first $h$ and then about $6-7 \mathrm{~h}$ in the $1-2 \frac{1}{2} \mathrm{~h}$ period after i.v. injection. Plasma HCG rose to -1 i.u. $/ 1$ after $1 \mathrm{~h}$ and further to 20 i.u./l $2 \frac{1}{2} \mathrm{~h}$ post i.m. injection in the animals given 750 i.u. and to 40 i.u./1 and further to $56 \mathrm{i} . \mathrm{u} . / \mathrm{l}$ in those given 1500 .

\section{DISCUSSION}

The low plasma testosterone 16 o'clock found in all 16 bulls during the control period is in agreement with previous observations in Norwegian Red Breed and Swedish Red and White Breed bulls (Sundby \& Tollman 1978, Oltner et al. 1979). No effect of HCG upon plasma testosterone levels in the 16 bulls was seen 5 or $15 \mathrm{~min}$ after injection. Similar results were observed following i.m. injection of 150 i.u. HCG to 4 dogs (Sundby \& Ulstein 1981). These studies give support to a former conclusion by Lindner (1961) that HCG does not have any immediate effect upon release of preformed hormone in the gland. On the other hand, following continuous infusion of HCG via the spermatic artery in dogs Eik-Nes (1967) reported elevated testosterone within the first min, followed by a decline and then a significant increase 8-12 min post injection and a most pronounced augmentation in hormone secretion 15-45 min after injection. Boyden et al. (1980) found increased testosterone secretion within 10 min following a single injection of 25 i.u. HCG into the spermatic vein in dogs. In rats plasma testosterone was found to increase above control 15 min following i.v. injection 
of 5 i.u. HCG and a substantial rise of testosterone in testicular tissue was measured $10 \mathrm{~min}$ after HCG administration (Purvis \& Haynes 1974). A slightly longer lag time for testicular responsiveness was found in rats in vitro although cyclic AMP increased within 1 min following addition of a high dose HCG, testosterone synthesis did not rise until 15 min later (Dufau et al. 1973). In the present investigation with bull in vivo an even longer lag time occurred. However, a shorter lag time was found following i.v. than i.m. injection ( 30 versus $45 \mathrm{~min}$ ) and the high plateau level was reached earlier following i.v. than i.m. HCG administration ( $1 \mathrm{~h}$ versus $1 \frac{1 / 2}{h}$ ). The difference in circulating HCG level following i.v. and i.m. injection may account for this difference. A relationship between the lag time of the testosterone response and the HCG dose has been reported in experiments with dogs in vivo (Boyden et al. 1980). The plateau level of plasma testosterone seems to depend more on the prestimulation maxima than on the dose or route of injection employed. This is in accordance with earlier observations in bulls (Sundby et al. 1975, Sundby \& Farahat 1978). Halflife of i.v. injected HCG was previously determined to be $13 \mathrm{~h}$ when estimated 1-20 h after injection (Sundby \& Torjesen 1978). In the present investigation halflife of i.v. injected HCG in bulls was estimated to be $75 \mathrm{~min}$ and $6-7 \mathrm{~h}$ in the periods $5-60 \mathrm{~min}$ and $1-2 \frac{1}{2} h$ post injection, respectively.

\section{ACKNOWLEDGEMENT}

The technical assistance of Randi Løes Skogstad is acknowledged.

\section{REFERENCES}

Boyden, T. W., R. W. Pamenter \& M. A. Silvert: Testosterone secretion by the isolated canine testis after controlled infusions of HCG. J. Reprod. Fertil. 1980, 59, 25-30.

Eik-Nes, $K$. B.: Factors influencing the secretion of testosterone in the anaesthetized dog. Ciba Found. Colloq. Endocrinol. (Proc) 1967, 16, 120-136.

Dufau, M. L., K. Watanabe \& K. J. Catt: Stimulation of cyclic AMP production by the rat testis during incubation with HCG in vitro. Endocrinology 1973, 92, 6-11.

Lindner, H. R.: Androgens and related compounds in the spermatic vein blood of domestic animals. I. Neutral steroids secreted by the bulls testis. J. Endocr. 1961, 23, 139-159. 
Oltner, R., K. Lundstrøm \& L. E. Edqvist: LH and testosterone in monozygous growing bulls. Swedish J. agric. Res. 1979, 9, 151161.

Purvis, K. \& N. B. Haynes: Short-term effects of copulation, human chorionic gonadotrophin injection and non-tactile association with a female on testosterone levels in the male rat. J. Endocr. $1974,60,429-439$.

Sand, T. \& P. A. Torjesen: Dextran-coated charcoal used in the radioimmunoassay of human pituitary luteinizing hormone. Acta endocr. 1973, 73, 444-454.

Sanwal, P. C., A. Sundby \& L. E. Edqvist: Diurnal variation of peripheral plasma levels of testosterone in bulls measured by a rapid radioimmunoassay procedure. Acta vet. scand. 1974, 15, $90-99$.

Sundby, A., R. Tollmann \& W. Velle: Long-term effect of HCG on plasma testosterone in bulls. J. Reprod. Fertil. 1975, 45, 249254.

Sundby, A. \& A. Farahat: Plasma testosterone in bulls: Response to various doses of HCG and PMSG. Acta endocr. 1978, 88, 793800.

Sundby, A. \& P. A. Torjesen: Plasma levels of testosterone in bulls: Response to repeated HCG injections. Acta endocr. 1978, 88, $787-792$.

Sundby, A. \& R. Tollman: Plasma testosterone in bulls. Seasonal variation. Acta vet. scand. 1978, 19, 263-268.

Sundby, A. \& T. Ulstein: Plasma concentrations of testosterone in the male dog and plasma testosterone profile following single intramuscular injection of HCG. Acta vet. scand. 1981, 22, 409-416.

\section{SAMMENDRAG}

Den фyeblikkelige effekt av HCG på plasma testosteron nivå hos okse.

Ingen effekt av HCG på plasma testosteron nivåt hos 16 okser kunne påvises de første 5 eller 15 minutter etter injeksjonen. Hos 8 okser som fikk 750 eller 1500 i.u. HCG ved intraven $\emptyset$ s injeksjon varte det 30 minutter f $\varnothing \mathrm{r}$ en $\varnothing \mathrm{kning}$ av plasma testosteron nivået kunne påvises. Høyt, stabilt plasma testosteron nivå kom ca. 1 time etter injeksjonen.

Etter intramuskulær injeksjon av 750 eller 1500 i.u. HCG ble det observert en ventetid på 45-60 minutter før testikulær respons målt som $\emptyset$ ket plasma testosteron nivå. Høyt, stabilt plasma testosteron hos disse oksene ble målt ca $1 \frac{112}{2}$ time etter injeksjonen.

(Received June 22, 1981).

Reprints may be requested from: A. Sundby, the Department of Physiology, Veterinary College of Norway, P.O. Box 8146, Dep., Oslo 1, Norway. 